\title{
Perception of Senior High School English Teachers and Students about Personal Competence
}

\author{
Aurora Paramahita Kusumawardhani, Utami Widiati, Fachrurrazy \\ English Language Education-Universitas Negeri Malang \\ Jl. Semarang 5 Malang. E-mail: araradhanysta@gmail.com
}

\begin{abstract}
This survey study was intended to investigate the perception of senior high school English teachers' and students about personal competence. Using Probability Simple Random Sampling, this study involved 35 English teachers and 246 students of public senior high schools in Kota Malang. Instruments used are questionnaires and interview guides for English teachers and students samples. The findings revealed that both English teachers and students perceived the English teachers' personal competence is very good. However, the English teachers' perception covered personal competence related to cognitive and affective skills. Meanwhile, the students' perception on personal competence only related to the affective skill.
\end{abstract}

Key Words: perception, English teachers, personal competence

\begin{abstract}
Abstrak: Penelitian survei ini bertujuan untuk mengetahui persepsi guru Bahasa Inggris dan peserta didik SMA mengenai kompetensi kepribadian. Menggunakan Probability Simple Random Sampling, penelitian ini melibatkan 35 guru Bahasa Inggris dan 246 peserta didik dari SMA-SMA Negeri di Kota Malang. Instrumen yang digunakan adalah kuesioner dan panduan wawancara untuk sampel guru Bahasa Inggris dan peserta didik. Hasil penelitian menunjukkan bahwa baik guru Bahasa Inggris ataupun peserta didik memperhatikan bahwa kompetensi kepribadian guru Bahasa Inggris sangat bagus. Namun, persepsi guru Bahasa Inggris meliputi kompetensi kepribadian yang berhubungan dengan kemampuan kognitif dan afektif. Sementara itu, persepsi peserta didik hanya berhubungan dengan kemampuan afektif.
\end{abstract}

Kata kunci: persepsi, guru bahasa Inggris, kompetensi kepribadian

In order to improve the quality of education in Indonesia, the government has declared a teacher as a professional worker whose responsibility in educating students and giving community services (UU No. 20/ 2013 bab XI pasal 39 ayat 2). In this case, Indonesian professional teachers are supposed to possess several qualifications, one of which is possessing excellent competences of pedagogy, personal, social, and subject matter. Indonesian teachers who show and integrate these competences in their professional performance are believed to be able to conduct teaching and learning process effectively so that learning goals are achieved. This condition is applied to teachers of all subject matter, including English.

Among the 4 competences which should be owned by English teachers, this study deals with the personal competence. According to PP No. 74/2008 bagian 1 pasal 3, personal competence relates to teachers' characters as an individual and a part of society in and out of school environment, including their role as good models for their students, colleagues, and society. This regulation implies that the Indonesian teachers should perform good personal competence as an educator and a member of the school and society. Besides, having excellent personal competence also means that the teachers should be able to be self-reflective and to develop and maintain their quality as teachers constantly and independently.

Moreover, professional teachers' obligation to their students does not only relate to teach and transfer learning material, but it also relates to guide and direct students in their emotional and social quotients. Therefore, professional teachers develop students who are outstanding in terms of academic achievement, but 
also in moral and ethics. By this means, the teachers succeed in educating students of Indonesia utterly as the national education goal stated. However, in order to achieve this success, the teachers should possess excellent personal competence first.

Studies have shown that personal competence teachers have is important in teaching and learning process. Embuena and Amoros (2012, p. 238-239) revealed that teachers' personal competence strongly related to effective classroom management. They stated that inadequate teachers' personal traits, such as abuse of authority and differentiated treat to students, could hinder the flow of effective classroom. These inadequate traits led to student' negative perception on the subject matter and teachers' profile besides led to poor teacher-students interaction. On another study, Liakopoulou (2011, p. 67) showed research result that teachers' personal traits became dominant and essential factors impacting to teaching effectiveness. It also maintained that teachers' personal competence, combining with their pedagogic competence, was necessary to overcome problems occurred in class (Liakopoulou, 2011, p. 72-73).

Mostly, teachers' personal competence is associated with good and effective teachers. Numerous studies have been conducted regarding this topic. Freire (1998 in Brady, 2011, p. 58) labelled teachers as human, emotionally responsive individuals, humility, lovingness, courage, tolerance, courage, tolerance, decisiveness, living the tension between patientce and impatience, and joy of living. Then, Rogers (1969 in Brady, 2011, p. 58) believed that teachers who support students' optimum learning had characters of emotionally and psychologically stable, realness, prizing, accepting, trust, empathic, understanding, and fully functioning person. Regarding inspiring students to achieve maximally in their learning, Rubio (2009, p. 43) listed that teachers should have skills of caring, understanding, fair, kind to students, passionate, enthusiastic, motivated as a teachers, being able to create warm and comfortable classroom, having sense of belonging, innovative, valuing diversity, and keeping a good teacher-students interaction. Borinca and Maliqi (2015) found that teachers who were enthusiastic, giving emotional support, showing a willingness to help students, understanding students' problem, creating an interactive environment, and having flexible personality inside and outside the classroom were able to raise students' learning motivation. Dealing with ideal teachers, Telli et al. (2008) showed that teachers were necessary to guide students, motivate and students, give confidence to students, be willing to keep positive relationship with students, and earn students' respect.

Meanwhile, Gurney (2007) found that a) teacher's knowledge, enthusiasm and responsibility in learning and b) effective interaction between the teacher and students, creating an environment that respects, encourages, and stimulates learning through experience were two of five factors essential for effective teaching. Liakopoulou (2011, p. 70) mentioned that love of children, love for the profession, personal drive to be effective, consistency, conscientiousness, imagination, creativity, sense of humour, determination, tenacity and enthusiasm contributed to teachers' effectiveness. Widayati (2002, p. 29, in Ahmad \& Setyaningsih, 2012, p. 95) stated that good teachers should a) understand the profession of teacher genuineness that teachers are the prestigious profession in society, b) give a positive reward during teaching and learning process so their students will do self-reward, c) not only show their sympathy but merely they have to show empathy, and d) realize that teachers should have ability to be a learner or long life learning and do not only keep in hand.

Concerning teaching of English, Park and Lee (2006, p. 246) found that to be effective, English teachers should build student' self-confidence and motivation, have a good sense of humour, treat students fairly, arise students' motivation, and listen to students' opinion. Similarly, Arikan et al. (2008) reported that English teachers needed to be friendly, young, enthusiastic, creative, and humorous regardless the gender. Shisavan and Sadeghi $(2009$, p. 134) showed that effective English teachers possessed good personality which were being patient and flexible, caring about students' needs, having positive attitudes towards learners, being smart, and creative, and do not talking too much about their personal experience. Relating to engage effective learning atmosphere, Hapsari (2013, p. 123-124) stated that English teachers had to be enthusiastic, resourceful and creative to succeed. Gashemi and Hashemi (2011, p. 414) revealed that effective English language teachers followed syllabus tightly, sticked to administrative rules and regulations and teaching techniques, were welldressed, were knowledgeable, were sociable, alleviated students' anxiety in class, and tried to arise students' motivation. Furthermore, Brown (2007, p. 491) provided characteristics of a good language teacher regarding personal qualities, which are a) being wellorganized, conscientious in meeting commitments, and dependable, $b$ ) being flexible when things go awry, 
c) engaging in regular reflection on one's own teaching practice and strives to learn from those reflective practices, d) maintains an inquisitive mind in trying out new ways of teaching, e) setting short-term and long-term goals for continued professional growth, and f) maintaining and exemplifying high ethical and moral standards.

Regarding this issue, Indonesian Ministry of National Education has also provided manual consisted of characteristics of a good and professional teacher in Instrumen Penilaian Kinerja Guru (Kemendiknas, 2011, p. 51-52). There are 3 competences and 18 indicators in the personal competence matter. The first competence is acting upon norms of religion, law, social, and national culture in Indonesia. This competence includes a) teachers' capability in valuing and promoting Pancasila principles as foundation of ideology and ethics for Indonesians, b) developing cooperation and togetherness with colleagues regardless races, religions, and gender, c) respecting and appreciating colleagues according to each condition and existence, d) having a sense of coalescence and unity as a part of Indonesia nation, and e) having a long view on Indonesia diversity. The second competence is showing a mature and exemplary individual. It covers teachers' traits in a) behaving appropriately in speaking, making an appearance, and acting to students, parents, and colleagues, b) willing to share their experiences with colleagues, including inviting colleagues to observe the teachers' teaching practices and then give inputs, c) being able to manage learning process showing that they are respected by the learners that learners always pay attention to the teachers and actively participated in the learning process, $d$ ) being mature in receiving inputs from learners and giving opportunity to learners to participate in the learning process, and e) having a good manner in order to maintain school honour. Lastly, the third competence Guru is a teacher's personal competence of having work ethic, high responsibility, and pride as a teacher. Indicators for this competence are a) teachers begin and end learning process on time, $b$ ) if teachers need to leave the class; they make students active by doing productive activities related to the subject matter, and ask teachers on duty or other teachers to supervise the class, c) teachers fulfill teaching hours and are able to do other activities beyond the teaching hours by school administers' permission and approval, d) teachers ask for permission and give an early notice, by providing valid reason and evidence, if they could not attend planned activities, including learning process in classroom, e) teachers finish all administrative and non-learning assignments punctually according to determined standards, $f$ ) teachers make use of unoccupied time with productive activities related to their duty as an educator, g) teachers contribute to school improvement and have achievements which positively affect school honour, and h) teachers are proud of their profession as educators.

This study focuses on personal competence possessed by English teachers. Thus, this study aims to investigate the English teachers' personal competence from perception of senior high school English teachers and students. Later on, the researcher does not only describe personal competence perceived by the English teachers and students, but also relates results from English teachers' and students' perception.

\section{METHOD}

This study employed survey research design since it deals with perception of English teachers and students on personal competence. Latief(2013, p. 124) stated that survey research is used for explaining opinions, attitudes, preferences, and perceptions of particular group of people. This research design provides numerical data; therefore quantitative analysis is required to explain the result of the findings. Survey research design also needs a large number of subjects, thus proper random sampling is necessary to determine representative samples.

Population of this study is all English teachers and students in all public senior high schools in Kota Malang. By the latest data obtained from Department of Education in Malang, there are 10 public senior high schools, 38 English teachers and 2,896 students in Kota Malang. In determining samples for this study, probability simple random sampling is used and it results 36 English teachers and 341 students as the samples. There were not any certain criteria for the English teacher samples. Meanwhile, for student samples, the researcher made use of students of XII or XI grade considering they had been taught by at least 2 different English teachers at schools. In fact, after distributing the questionnaires, there were only 35 English teachers and 246 students participated in this study.

There are two research instruments for this study. They are English teachers' and students' questionnaires and English teachers' and students' interview guides. The questionnaires were developed by the re- 
searchers based on indicators of teacher' personal competence adapted from characteristics to be a good and professional teacher in Instrumen Penilaian $\mathrm{Ki}$ nerja Guru (Kemendiknas, 2011, p. 51-52) and in results of experts researchers (Freire, 1998 and Rogers, 1969 in Brady, 2011; Rubio, 2009; Park \& Lee, 2006; Arikan et al., 2008; Borinca \& Maliqi, 2015; Telli et al., 2008; Shisavan \& Sadeghi, 2009; Gurney, 2007; Hapsari, 2013; Liakopolou, 2011; Widayati, 2002 in Ahmad \& Setyaningsing, 2012; Brown, 2007; Gashemi \& Hashemi, 2011). There are 22 values included in these questionnaires, which are (a) nationalistic; (b) cooperative; (c) open-minded; (d) flexible; (e) well-mannered; (f) punctual; (g) disciplined; (h) obedient; (i) motivated, enthusiastic, and determined; (j) productive; (k) creative and innovative; (l) responsible; (m) confident and proud; (n) knowledgeable; (o) communicative and interactive; (p) warm; (q) encouraging and motivating; (r) fair; (s) caring, emphatic and helpful; ( $\mathrm{t}$ ) patient and pleasing; $(\mathrm{u})$ respected; and $(\mathrm{v})$ respectful. These questionnaires were in the form of four point Likert-type scale which ranged from "strongly agree" (1 point) to "strongly agree" (4 point). The questionnaires were provided in Bahasa Indonesia and there were 46 items in each of English teachers' and students' questionnaires. Meanwhile, the interview guides for English teachers and students were semi-structured and used for gaining supplementary in-depth information of English teachers' and students' perception on personal competence. There were 10 questions in English teachers' interview guide and 13 questions in students' interview guides which were derived from the items in the questionnaires.

In employing the questionnaires, the researchers distributed the questionnaires either by presenting herself before the samples or by being assisted by one of teachers in the schools. For the interviews, the researcher questioned 3 English teachers and 6 students from representative schools which are selected based on random sampling. Data obtained from the questionnaires analyzed quantitatively, while data obtained from the interviews analyzed qualitatively. The data analysis of this study followed the following order: (a) checking and sorting questionnaires, (b) tabulating the data, (c) presenting each item answers in a table based on the number of option types, (d) interpreting quantitative data, (e) transcribing interview results, and (f) interpreting and combining quantitative and qualitative data.

\section{RESULTS}

\section{English Teachers' Perception on English Teachers' Personal Competence}

In this sub-chapter, it is presented data obtained from English teachers' questionnaire to know their perception on personal competence. The presented data are analyzed according to the 22 determined values on personal competence in this study. The whole data of English teachers' perception on their own personal competence is presented in Table 1 .

Based on Table 1, the total average mean score of English teachers' personal competence is $89.68 \%$, included in the very good category. The table also displays that the English teachers perceived most of the determined values as very good. The researcher took values which have average $90 \%$ and more as the highest and, then, the most prominent values showing in their perception. The highest and the most prominent values referred are the value of flexible $(90.5 \%)$; caring, emphatic, and helpful (90.91\%); responsible (91\%); warm (91.37\%); well-mannered (93.75\%); encouraging and motivating (94.5\%); open-minded $(94.62 \%)$; cooperative (95\%); punctual $(95 \%)$; communicative and interactive (95\%); con-fident and proud $(95.5 \%)$; respectful (96.83\%); and fair (97\%). This result shows that the English teachers in Malang perceived that they truly have very good personal competence which they showed and performed during their activities at school.

\section{Students' Perception on English Teachers' Personal Competence}

This sub-chapter presents data obtained from students' questionnaire relating their perception on their English teachers' personal competence. Similar to the English teachers' questionnaire, analysis of this data is carried out based on the 22 determined values in this study. This students' data is also used to balance and verify data obtained from the English teachers. The complete data of students' perception on their English teachers' personal competence is presented in Table 2.

According to data displayed in Table 2, the average mean score of all English teachers' personal value from the students' perception is $77,30 \%$, included in very good category. Although the average mean score 
Table 1. The Accumulative Table of Average Scores as Per Determined Values from English Teachers' Perception

\begin{tabular}{|c|c|c|c|c|c|c|}
\hline No & Values & TI & TIS & TRA & RAA & $\mathbf{A P}(\%)$ \\
\hline 1. & Nationalistic & 3 & 12 & 375 & 10.71 & 89.25 \\
\hline 2. & Cooperative & 1 & 4 & 133 & 3.80 & 95 \\
\hline 3. & Open-minded & 2 & 8 & 265 & 7.57 & 94.62 \\
\hline 4. & Flexible & 1 & 4 & 127 & 3.62 & 90.50 \\
\hline 5. & Well-mannered & 3 & 12 & 394 & 11.25 & 93.75 \\
\hline 6. & Punctual & 1 & 4 & 133 & 3.80 & 95 \\
\hline 7. & Disciplined & 2 & 8 & 227 & 6.48 & 81 \\
\hline 8. & Obedient & 2 & 8 & 246 & 7.02 & 87.75 \\
\hline 9. & $\begin{array}{l}\text { Motivated, Enthusiastic, and } \\
\text { Determined }\end{array}$ & 3 & 12 & 356 & 10.17 & 84.75 \\
\hline 10. & Productive & 2 & 8 & 206 & 5.88 & 73.50 \\
\hline 11. & Creative and Innovative & 2 & 8 & 226 & 6.45 & 80.62 \\
\hline 12. & Responsible & 2 & 8 & 255 & 7.28 & 91 \\
\hline 13. & Confident and Proud & 1 & 4 & 134 & 3.82 & 95.50 \\
\hline 14. & Knowledgeable & 1 & 4 & 115 & 3.28 & 82 \\
\hline 15. & Communicative and Interactive & 2 & 8 & 266 & 7.60 & 95 \\
\hline 16. & Warm & 2 & 8 & 256 & 7.31 & 91.37 \\
\hline 17. & Encouraging and Motivating & 3 & 12 & 397 & 11.34 & 94.50 \\
\hline 18. & Fair & 1 & 4 & 136 & 3.88 & 97 \\
\hline 19. & Caring, Emphatic, and Helpful & 3 & 12 & 382 & 10.91 & 90.91 \\
\hline 20. & Patient and Pleasing & 4 & 16 & 499 & 14.25 & 89.06 \\
\hline 21. & Respected & 2 & 8 & 236 & 6.74 & 84.25 \\
\hline \multirow[t]{2}{*}{22.} & Respectful & 3 & 12 & 407 & 11.62 & 96.83 \\
\hline & TOTAL/AVERAGE & 46 & 184 & 5771 & 164.78 & 89.68 \\
\hline \multicolumn{7}{|l|}{ Notes: } \\
\hline TI & \multicolumn{6}{|l|}{ : Total Items } \\
\hline TIS & \multicolumn{6}{|l|}{ Total Item Score } \\
\hline TRA & \multicolumn{6}{|l|}{ : Total Respondents' Answers } \\
\hline RAA & \multicolumn{6}{|c|}{ : Respondents' Answer Average $=$ TRA $/$ Total Respondents (35 people) } \\
\hline $\mathrm{AP}$ & \multicolumn{6}{|c|}{ : Average in Percentages $=$ RAA $/$ TIS x $100 \%$} \\
\hline
\end{tabular}

is very close to good category ( $76 \%$ ), most of values from the students' perception are categorized very good. Different from English teachers' perception data, there is not any values reaching $90 \%$ average mean score in the students' perception data. Therefore, the researcher took values with $80 \%$ and more average mean score as the highest and, then, the most prominent values of English teachers' personal competence perceived by the students. The referred values are confident and proud value $(80 \%)$, warm value $(80.12 \%)$, well-mannered value $(82.41 \%)$, respectful value $(82.58 \%)$, and fair value $(83.25 \%)$. Based on this result, it shows that students truly regarded that their English teachers' personal competence was real$l y$ showed and performed excellently.

\section{English Teachers' and Students Interview Results}

Interview sessions result presented here is the additional information for the result of questionnaires about English teachers' personal competence. Repre- sentatives of either the English teachers' or students' samples were questioned for this need.

From English teachers' interview session, it was known that the English teachers really showed their high-quality personal competence during their activities at schools, including when they were interacting with students. It is revealed that the English teachers attended flag ceremonies (nationalistic), attended their scheduled class punctually (punctual), provided proper assistance and encouragement when students doing learning tasks (helpful, encouraged), renewed their knowledge and use of technology for their teaching (knowledgeable, open-minded), and were pleased and proud to be teachers. Moreover, the English teachers stated that good English teachers should update the latest information in learning materials to improve students' ability in teaching matters to enhance their competence as teachers, renew their knowledge to understand how to treat students well by balancing positive traits in their personality, understand what essential things students need to learn English well, provide culture learning and real situation to learn English, and 
Table 2. The Accumulative Table of Average Scores as Per Determined Values from Students' Perception

\begin{tabular}{|c|c|c|c|c|c|c|}
\hline No & Values & TI & TIS & TRA & RAA & $\mathbf{A P}(\%)$ \\
\hline 1. & Nationalistic & 3 & 12 & 2346 & 9.53 & 79.41 \\
\hline 2. & Cooperative & 1 & 4 & 737 & 2.99 & 74.75 \\
\hline 3. & Open-minded & 2 & 8 & 1493 & 6.06 & 75.75 \\
\hline 4. & Flexible & 1 & 4 & 757 & 3.07 & 76.75 \\
\hline 5. & Well-mannered & 3 & 12 & 2434 & 9.89 & 82.41 \\
\hline 6. & Punctual & 1 & 4 & 748 & 3.04 & 76 \\
\hline 7. & Discipline & 2 & 8 & 1490 & 6.05 & 75.62 \\
\hline 8. & Obedient & 2 & 8 & 1518 & 6.17 & 77.12 \\
\hline 9. & $\begin{array}{l}\text { Motivated, Enthusiastic, and } \\
\text { Determined }\end{array}$ & 3 & 12 & 2250 & 9.14 & 76.16 \\
\hline 10. & Productive & 2 & 8 & 1320 & 5.36 & 67 \\
\hline 11. & Creative and Innovative & 2 & 8 & 1388 & 5.64 & 70.5 \\
\hline 12. & Responsible & 2 & 8 & 1570 & 6.38 & 79.75 \\
\hline 13. & Confident and Proud & 1 & 4 & 798 & 3.20 & 80 \\
\hline 14. & Knowledgeable & 1 & 4 & 736 & 2.99 & 74.75 \\
\hline 15. & Communicative and Interactive & 2 & 8 & 1558 & 6.33 & 79.12 \\
\hline 16. & Warm & 2 & 8 & 1579 & 6.41 & 80.12 \\
\hline 17. & Encouraging and Motivating & 3 & 12 & 2323 & 9.44 & 78.66 \\
\hline 18. & Fair & 1 & 4 & 820 & 3.33 & 83.25 \\
\hline 19. & Caring, Emphatic, and Helpful & 3 & 12 & 2274 & 9.24 & 77 \\
\hline 20. & Patient and Pleasing & 4 & 16 & 2956 & 12.01 & 75.06 \\
\hline 21. & Respected & 2 & 8 & 1556 & 6.32 & 79 \\
\hline \multirow[t]{2}{*}{22.} & Respectful & 3 & 12 & 2440 & 9.91 & 82.58 \\
\hline & TOTAL/AVERAGE & 46 & 184 & 35091 & 142.5 & 77.30 \\
\hline \multicolumn{7}{|l|}{ Notes: } \\
\hline TI & \multicolumn{6}{|l|}{ : Total Items } \\
\hline TIS & \multicolumn{6}{|l|}{ : Total Item Score } \\
\hline TRA & \multicolumn{6}{|l|}{ : Total Respondents' Answers } \\
\hline RAA & \multicolumn{6}{|c|}{ : Respondents' Answer Average $=$ TRA $/$ Total Respondents $(246$ people $)$} \\
\hline AP & \multicolumn{6}{|c|}{ : Average in Percentages $=$ RAA / TIS x $100 \%$} \\
\hline
\end{tabular}

recognize students' individual ability so that they could be fairly assessed. Besides, good English teachers should be active in class. They needed to give proper modelling in producing language to students, thus students could be motivated to learn English.

Students' interview sessions result confirmed the result of English teachers' interviews. The students stated that they enjoyed their English class since the English teachers were pleasing, patient, motivating, and warm. The students also maintained that their English teachers' enthusiasm, helpfulness and well manners made them motivated in learning English better. These positive values performed by the English teachers made the students respect their teachers and created good teacher-students' relationship. Besides, their English teachers utilized online materials and learning media thus the students felt easy to understand and follow learning activities at class. Furthermore, the students suggested good English teachers had to be determined in teaching, open-minded and knowledgeable besides creative and innovative in order to provide proper learning materials and media at class, understandable students' individual abilities, giving clear explanation, friendly, and cheerful. In addition, the English teachers should also be caring, patient, humble, and kind to build comfortable atmosphere so that students could learn English pleasingly.

In conclusion, both English teachers' and students' opinions on ideal English teachers are similar in some extent. Their ideal English teacher is the one who is knowledgeable, understandable, open-minded and active as well as cheerful. However, students regard motivated, determined, open-minded, knowledgeable, creative, and innovative values more than the other values. Meanwhile, the English teachers signify knowledgeable and understandable values more than the others.

\section{DISCUSSION}

This study aims at investigating English personal competence from perception of English teachers and students. Result of collected data was analyzed and then analyzed according to the 22 determined value of this study, which are (a) nationalistic; (b) cooperative; (c) open-minded; (d) flexible; (e) well-mannered; 
(f) punctual; (g) disciplined; (h) obedient; (i) motivated, enthusiastic, and determined; (j) productive; $(\mathrm{k})$ creative and innovative; (l) responsible; (m) confident and proud; (n) knowledgeable; (o) communicative and interactive; (p) warm; (q) encouraging and motivating; (r) fair; (s) caring, emphatic and helpful; $(\mathrm{t})$ patient and pleasing; (u) respected; and (v) respectful.

The first value is nationalistic, relating to English teachers' nationalism showed during their daily activities in school. The teachers showed this value by attending flag ceremonies, using proper Bahasa Indonesia, and motivating students to be capable of competing with students from other countries. As role models for students, it is important for teachers to have good nationalistic value since they can promote sense of loyalty and develop understanding of national identity to students (Rawantina \& Arsana, 2013, p. 40; Kukoviè \& Haæek, 2014: 2; Kahne \& Middaugh, 2006, p. 602). The second value is cooperative, which relates to English teachers' willingness to work together either with students or with their colleagues at school. This cooperation does not only in terms of teacher-students cooperation during class activities, but also teacherstudents and teacher-school staffs cooperation in school events. Regarding teachers' cooperation with students, Suplicz (2009, p. 133) stated that teachers' cooperativeness is important in building teachers' role in students' image and that it can influence teaching efficiency.

The third is open-minded value, dealing with the English teachers' willingness to accept new ideas beyond their perspective. English teachers who are open-minded give positive response to students' critics and suggestions as well as are willing to learn new information. Dewey (1993 in Farrel, 2008, p. 1) maintained that teachers who were open-minded could be categorized as reflective individuals. Thus, the teachers were able to improve their knowledge and made their students learn effectively. The fourth value is flexible, which deals with English teachers' ability in adjusting themselves within any situations they are into. English teachers who are flexible in their personality both inside and outside the class are believed to be able to conduct teaching and learning activities more effectively (Borinca \& Maliqi, 2015; Shisavan \& Sadeghi, 2009, p. 134).

The fifth value is well-mannered, which has to do with the English teachers' trait on having good behavior to other people either in terms of speech or action. English teachers samples in this study truly showed their excellent well-mannered value by showing good manners to their colleagues and to their students when they were inside and outside the classroom. Gashemi and Hashemi (2011, p. 414) called this kind of teachers as successful language teachers since this value influence students' learning positively by creating comfortable learning environment for students (Shisavan $\&$ Sadeghi, 2009, p. 135). The sixth value is punctual, which observed on how the English teachers' commitment to accomplish their duty on determined schedule. The English teachers performed this value by beginning and ending the lesson on time as the schedule. When the English teachers come on time to the classroom, the students will feel respected (Delaney et al., 2010, p. 17). Besides, by conducting the class on the schedule, it means that the teachers make use of the provided maximally so that the learning can be held effectively (Stronge et al., 2011 in Aina et al., 2015, p. 93).

The seventh value is disciplined, dealing with teachers' strictness in conducting learning process. Based on the result of this study, the English teachers preferred to give tolerance for students coming 5-10 minutes late to the class. Nevertheless, if they came later than the time of tolerance, the students were not allowed to attend that meeting and were punished to do certain tasks outside the class. English teachers need to understand well in the use of proper discipline in managing the class. Teachers who recognize appropriate degree of discipline applied in the class are capable of creating conducive and encouraging learning atmosphere (Barton et al., 1998 in Rahimi \& Karkami, 2015, p. 58). The eighth value is obedient, dealing the English teachers' trait in obeying regulations, such as providing valid reason and early permission if they cannot attend certain school activities and giving punishment to students as the school regulation. Obedient teachers do not only reflect their professionalism through their obedience, but also their obedience can keep them from having problems hindering their planned teaching and learning process (Gashemi \& Hashemi, 2011, p. 414).

The ninth value is the value of motivated, enthusiastic, and determined. It regards English teachers' quality in conducting class and contributing to school activities. The English teachers in this study have been perceived to be very good in teaching the class enthusiastically, varying each meetings eagerly, and being diligent. These teachers were expected to give significant contribution to students' effective learning (Rubio, 2009, p. 43; Liakopoulou, 2011, p. 70). Moreover, the teachers' motivation, enthusiasm, and determination 
in conducting the lesson can affect the students' attitude to be more motivated in their learning (Moskovsky et al., 2013 in Hapsari, 2013, p. 117). The tenth value is productive, reflecting the English teachers' involvement in various activating relating to their teaching and to their duty as school staffs. The English teachers in this study have been recognized to be productive either in developing learning materials or in school events. The teachers' productive attitudes can enhance students' performance in learning and improve the school success in certain ways (Vipinosa, 2016, p. 452).

The eleventh value is the value of creative and innovative, dealing with varieties the English teachers presented in conducting teaching and learning process. The English teachers performed this value well by providing enough variation in their use of media when conducting the lesson. The teachers' creativeness and innovation are believed to be able to "survive the demands, threats and challenges within the diverse circumstances of teaching" (Gibbs, 2002 in Rubio, 2009, p. 36) and to support students' natural learning (Smith, 1995 in Rubio, 2009, p. 36). The twelfth value is responsible, relating to the English teachers' commitment to fulfill their duties. The English teachers showed that they had very good responsible value with doing their duties as educators or as committee of school events corresponding to school standards in full sense of responsibility. Lauermann (2013, p. 145-163) said that responsible teachers were believed to be a good role model for their students while they were capable of achieving "desirable educational outcomes".

The thirteenth value is the value of confident and proud, which is important for the English teachers to perform their professional activities well. In this study, the English teachers were truly proud of their profession as Indonesian teachers and performed their teaching confidently. The teachers who show confident and proud value indicated that they love their profession. It is important for English teachers to be confident and proud since this value can be promoted to students' learning attitude which leads to their motivation to learn better (Rubio, 2009, p. 40). The fourteenth value is knowledgeable, dealing with English teachers' trait to update their knowledge in general and in the use of technology. The English teachers realized rapid development and spreading of the latest information, thus they were eager to always renew their knowledge in general and their ability in using the latest technology. This kind of teachers knows what and how to teach to their students since they have adjusted their knowl- edge with current information and, then, create students' effective learning environment (Gurney, 2007, p. 91).

The fifteenth value is the value of communicative and interactive, dealing with English teachers' ability in involving and interacting in their community. The English teachers in this study showed very good communicative and interactive value by willing to listen to others' opinions and involving students in class discussion. English teachers whose good communicative and interactive value are able to build interactive, healthy, and encouraging classroom environment so that students' can learn comfortably and effectively (Gurney, 2007 , p. 95), leading to their improvement of learning quality and achievement (Stronge et al., 2004 in Rubio, 2009 , p. 43). The sixteenth value is warm, concerning the English teachers' attribute in showing their kindness and friendliness to people around them. The English teachers truly showed their warm value by being attentive to students inside and outside the classroom and giving smile to everybody at school. Warm teachers can encourage learning environment in classroom (Gurney, 2007, p. 95) which support students' to learn effectively.

The seventeenth value is the value of encouraging and motivating, dealing with reinforcement and inspiration the English teachers give for students' learning development in terms of speech. The English teachers had given proper encouragement and motivation by giving compliments instead of criticism to students and motivating them to pursue their dreams. Besides being able to build effective learning environment, motivating and encouraging students need to be maintained by the teachers since it contributes significantly to students' learning success (Hapsari, 2013, p. 114-115). The eighteenth value is fair, regarding the English teachers' equal treatment to their students. The English teachers showed their very good fair value by treating all of their students the same despite of the students' social status or religion and giving equal treatment to students whom they taught and those whom they did not taught. By treating the students fairly, the English teachers have established encouraging learning atmosphere for students (Kyriacou, 1998 in Rubio, 2009, p. 40).

The nineteenth value is the value of caring, emphatic, and helpful, dealing with the English teachers' trait in treating students when they have difficulties. When the English teachers were observing students doing assignment in class, they showed that they were truly willing to listen to students' difficulties in learning, 
aware if the students had obstacle in their learning, and willing to assist students when they had learning problems. The teachers whose good caring, emphatic, and helpful value are believed to be able to optimize students' learning (Shisavan \& Sadeghi, 2009) and create conducive classroom in which students learn comfortably (Rubio, 2009, p. 43). The twentieth value is the value of patient and pleasing, which makes students feel comfortable around English teachers who have this value well. The English teachers in this study had very good patient and pleasing value for they did not insult students in their speech, they allowed unwell students to leave the class, and they made student feel comfortable around them. Patient and pleasing English teachers are preferable by students since they provide enjoyable language learning climate in class, thus this value is one of characteristics of effective English teachers (Arikan et al., 2008, p. 43; Shisavan \& Sadeghi, 2009, p. 135).

The twenty-first value is respected, relating to honor to the English teachers given by students and other people at school. In this study, the English teachers were well respected by students and their colleagues at schools. When the English teachers are respected by their students, they can manage learning process thoroughly and be paid attention by students in class (Kemendiknas, 2011, p. 52). The last value is respectful, which deals with English teachers' trait in appreciating other people during their interaction in their community. The English teachers in Malang showed very good respectful value by apologizing when they made mistakes, asking for help in right manner, and thanking after being helped appropriately. Teachers whose excellent respectful value can build good teacher-students relationship which then minimize psychological distance which may hinder them from understanding students' need (Rubio, 2009; Telli et al., 2008; Hattie, 2003, p. 8).

\section{Conformity between English Teachers' and Students' Perception}

This perception conformity is drawn based on data obtained from English teachers and students. From the whole questionnaires and interviews results of English teachers and students, it is revealed that the English teachers perceived the personal competence more thoroughtly. Data shows that the values the English teachers frequently stated in both questionnaire and interview, cover values related to cognitive and affective skills in balance. Meanwhile, the students' data concerns more values relating to affective skills only. It means that there is different tendency between English teachers' and students' perception. This difference might occur due to distinct need of the English teachers and students in their activity during teaching and learning process. English teachers need to possess complete understanding on knowledge of English, the latest information on general knowledge, and technology development to conduct meaningful language class for students. In this case, the teachers should have excellent cognitive and affective skills. On the other hand, the students only need to have conducive and effective learning environment for their success in learning, therefore they may focus only to their teachers' affective skill since this skill contributes significantly to the establishment of learning atmosphere in class (Shisavan \& Sadeghi, 2009).

\section{CONCLUSION}

According to the data analysis of this study, it shows that in general the English teachers' personal competence is very good. From the English teachers' perception, it is revealed that the English teachers' most prominent characteristics are the value of flexible; caring, emphatic, and helpful; responsible; warm; well-mannered; encouraging and motivating; openminded; cooperative; punctual; communicative and interactive; confident and proud; respectful; and fair. Besides, those teachers suggested that English teachers' personal competence was good if the teachers were also active in class and understanding students' individual ability. Meanwhile, the students perceived that the most prominent characteristics of English teachers' personal competence are the value of confident and proud, warm, well-mannered, respectful, and fair, of which are also included to the English teachers' most prominent characteristics. In addition, the students stated that they preferred English teachers who are understanding students' ability, cheerful, humble, and giving clear explanation.

Then, the most prominent values suggested by the students are included in the most prominent values from English teachers' perception. In interview sessions, both English teachers and students stated that English teachers should have good competence in knowledgeable value and in understanding students' individual abilities. Concerning overall result of this study, it can be concluded that the English teachers' perception on personal competence is more thoroughly than the students. The English teachers' perception 
on their personal competence is prominent in relation to cognitive and affective skills. On the other hand, the students' perception is only prominent in values related to affective skills. This slightly different result is probably caused by different knowledge in the need of teaching and learning process. What students know is they need an English teacher who performs well so that they can learn enjoyable English class and what they see is the teacher's performance in teaching English and how the teacher assists them in understanding English materials. Meanwhile, English teachers have complex duties as teachers. They should pay attention to materials and teaching method they use so that students can comprehend and achieve well in English. The English teachers also need to present themselves well since they realize that it is their obligation to be a role model for their students and society. Besides, the English teachers' personal competence can give significant impact to the success of learning activities, students' achievement, and students' non-academic attitudes.

This study only gives description on what values which are prominent on English teachers' personal competence and on how good English teachers' personal competence is from perception of senior high school English teachers and students in Malang. Criteria used in determining samples of this study was only that the schools where the English teachers and students sample conducted teaching and learning process were considered as favourite school in Kota Malang. Therefore, it is suggested further researchers conduct studies on this topic with more varied criteria in determining samples of the study, such as period of teaching and age for English teachers or gender and degree of learning achievement for students. The further researchers are also expected to conduct studies regarding which values of personal competence stated in this study have the most significant contribution to students' learning achievement. Besides, they can also manage a study on the degree of English teachers' personal competence influencing students' learning effectiveness.

\section{REFERENCES}

Ahmad. \& Setyaningsih, E. (2012). Teacher Professionalism: A Study on Teachers' Professional and Pedagogic Competence at Junior, Senior, and Vocational High Schools in Banyumas Regency, Central Java, Indonesia. Sosiohumanika, (Online), 5( 1): 93-106.
Aina, J. K., Olanipekun, S. S. \& Garuba, I. A. (2015). Teachers' Effectiveness and Its Influence on Students' Learning. Advances in Social Sciences Research Journal, 2(4):88-95.

Arikan, A., Ta ${ }^{\circ}$ r, D. \& Saraç-süzer, H. S. (2008). The Effective English Language Teacher from the Perspectives of Turkish Preparatory School Students. Education and Science, 33(150):42-51.

Borinca, I. \& Maliqi, A. (2015). The Influence of Teachers on Increasing Students' Motivation to the Ismail Qemaili High School in the City of Kamenica, Kosovo. Psychology, 6:915-921. http://dx.doi.org/10.4236 /psych.2015.68089.

Brady, L. (2011). Teacher Values and Relationship: Factors in Values Education. Australian Journal of Teacher Education,(Online), 36(2):56-66. http://dx.doi.org/ 10.14221/ajte.2011v36n2.5.

Brown, H. D. (2007). Teaching by Principles, an Interactive Approach to Language Pedagogy, $3^{\text {rd }}$ Ed. New York: Pearson Education.

Delaney, J., Johnson, A., Johnson, T. \& Treslan, D. (2010). Students'Perception of Effective Teaching in Higher Education. Project report published for $26^{\text {th }} \mathrm{An}$ nual Conference on Distance Teaching and Learning. St. John's: Memorial University of Newfoundland.

Departemen Pendidikan Nasional. (2003). Undang-Undang No. 20 tahun 2003 tentang Sistem Pendidikan Nasional. Jakarta: Departemen Pendidikan Nasional.

Departemen Pendidikan Nasional. (2008). Peraturan Pemerintah No. 74 tahun 2008 tentang Guru. Jakarta: Departemen Pendidikan Nasional.

Embuena, V. C. \& Amoros, M. J.H. (2012). Building Pre-Service Teachers' Identity: the Value of Dialogue within the Classroom. Journal of Human Sport \& Exercise, 12(1): 227-242.

Farrel, T.S.C. (2008). Reflective Practice in the Professional Development of Teachers of Adult English Language Learners. CAELA Network, (Online), October 2008: 1-4, (http://www.teslontario.org/uploads/ research/ReflectivePracticeFinalWeb\%20Farrell. pdf.), accessed on $25^{\text {th }}$ of November 2016.

Gashemi, B. \& Hashemi, M. (2011). The Study of the Characteristics of Successful English Language Teachers from the View Point of the English Language Students of Islamic Azad University, Hamedan Branch. Social and Behavioral Sciences, 28,411-415.

Gurney, P. (2007). Five Factors for Effective Teaching. New Zealand Journal of Teachers' Work, 4(2):89-98.

Hapsari, W. (2013). Teacher's Perceived Characteristics and Preferences of Motivational Strategies in the Language Classroom. TEFLIN Journal, 24, 113-134. 
Hattie, J. (2003). Teachers Make a Difference, What is the Research Evidence? Paper presented at the Building Teacher Quality: What does the research tell us ACER Research Conference, Melbourne Australia. (Online) (http://research.acer.edu.au/research_ conference_2003/4/), accessed on $5^{\text {th }}$ of December 2016.

Kahne, J. \& Middaugh, E. (2006). Is Patriotism Good for Democracy? A Study of High School Seniors' Patriotic Commitments. Phi Delta Kappan, (Online) 87(8):600-607.

Kementrian Pendidikan Nasional. (2011). Pedoman Pelaksanaan Penilaian Kinerja Guru (PK Guru), Buku 2. Jakarta: Direktorat Jenderal Peningkatan Mutu Pendidik dan Tenaga Kependidikan, Kementerian Pendidikan Nasional.

Kukoviè, S. \& Haæek, M. (2014, July). Attitudes towards Active Citizenship and Patriotic Education among Slovenian Youth. Paper presented atISA, XVIII World Congress of Sociology Yokohama, Japan.

Latief, M. A. (2013). Research Methods on Language Learning: An Introduction. Malang: State University of Malang Press.

Lauermann, F. V. (2013). Teacher Responsibility: Its Meaning, Measure, and Eductaional Implications. Published Dissertation. Ann Arbor: University of Michigan, Retrieved from: https:/deepblue.lib.umich.edu/ bitstream/handle/2027.42/99839/fanim _ 1.pdf?sequence $=1$.

Liakapoulou, M. (2011). The Professional Competence of Teachers: Which Qualities, Attitudes, Skills, and Knowledge Contribute to a Teacher's Effectiveness?. International Journal of Humanities and Social Science, 1, 66-78.

Park, G. P. \& Lee, H. W. (2006). The Characteristics of Effective English Teachers as Perceived by High School Teachers and Students in Korea. Asia Pacific Education Review, 7, 236-248. Retrieved from http://files. eric.ed.gov/fulltext/EJ752344.pdf.
Rahimi, M. \& Karkami, F. H. (2015). The Role of Teachers' Classroom Discipline in Their Teaching Effectiveness and Students' Language Learning Motivation and Achievement: A Path Method. Iranian Journal of Language Teaching Research, 3(1),57-82. Retrieved from http://www.urmia.ac.ir/sites/www. urmia.ac.ir/files/Article4.pdf.).

Rawantina, N.I. \& Arsana, I M. (2013). Penanaman Nilai Nasionalisme dan Patriotisme untuk Mewujudkan Pendidikan Karakter pada Mata Pelajaran Pendidikan Kewarganegaraan Siswa Kelas X SMA Negeri 4 Sidoarjo. Kajian Moral dan Kewarganegaraan, 1(1), 39-54, Retrieved from http://ejournal.unesa.ac.id/ article/2875/41/article/pdf.

Rubio, C.M. (2009). Effective Teachers-Professional and Personal Skills. ENSAYOS, Revista de la Facultated de Educación de Albacete, 24, 35-46. Retrieved from http://dialnet.unirioja.es/descarga/articulo/ 328243.pdf.

Shisavan, H. B. \& Sadeghi, K. (2009). Characteristics of an Effective English Language Teacher as Perceived by Iranian Teachers and Learners of English. English Language Teaching, 2(4), 130-143. Retrieved from http://www.ccsnet.org/journal/index.php/elt/article/ viewFile/4462/3803.

Suplicz, S. (2009). What Makes a Teacher Bad?-Trait and Learnt Factors of Teachers' Competencies. Acta Polytechnica Hungarica, 6(3),125-138, Retrieved from: http://uni-obuda.hu/journal/Suplicz_19.pdf.

Telli, S., Brok, P. \& Çakirglou, J. (2008). Teachers' and Students' Perceptions of the Ideal Teacher. Education and Science, 33(149), 118-129, Retrieved from http:/ /egitimvebilim.ted.org.tr/index.php/EB/article/ viewFile/645/117.

Vipinosa, L. D. (2015). Productivity in the Academe: An Inquest towards Teaching Effectiveness. International Journal of Multidisciplinary and Current Research, 3(3), 452-456 Retrieved from http:// ijmcr.com/wp-content/uploads/2015/05/Paper10452456.pdf. 